\title{
A Critical Assessment of Draft Indian National Education Policy 2019 with respect to National Institutes of Technical Teachers Training and Research
}

\author{
Thanikachalam Vedhathiri, \\ Former Professor and \\ HOD, Center for International Affairs, \\ National Institute of Technical Teachers Training \\ and Research, \\ Chennai-600113, India \\ vthani2025@yahoo.in
}

\begin{abstract}
The gaps with respect to engineering faculty training and development in the draft National Education Policy 2019 (NEP 2019) have been identified. The NEP 2019 totally neglected the role, contribution and the desired growth beyond 2020 of four National Institutes of Technical Teacher Training and Research (NITTTRs). Also, there is no mention of the Polytechnic Colleges which substantially contributed to the industrial development through well trained technicians. Further, the role of various Professional Associations, Boards of Apprenticeship Training, linkages of engineering institutes, industries, government and society have been omitted. Moreover, the desired growth of Type-I universities has not been considered beyond research works. The critical analyses have brought the gaps in the policy document and the remedial measures are to be included in the validated policy document. Considering the reputation at global level, the future proactive roles of four NITTTRs are synthesized and presented.
\end{abstract}

Keywords: NEP2019, Role of Polytechnic Colleges, Role of NITTTRs, Multidisciplinary postgraduate and doctoral engineering teacher education.

\section{Introduction}

The Draft National Education Policy 2019 has been submitted by the committee of experts to the Minister for Human Resource Development (HRD) in May 2019. There is a need for evaluation and validation of the NEP 2019 so that the improvements could be incorporated in it before the parliament approves it. Once it is approved next ten years the funding from the governments would be based on the NPE 2019. All the engineering graduates face a very tough problem of meeting the industrial skill needs due to fast growth on innovations in design, production of equipment, machines and services due to disruptive advanced technologies. The engineering profession is interested in government support to continuously modernize the engineering education so that they can contribute to the growth.

\section{Need for Research}

There is an urgent need to fill up the gaps in the draft NEP 2019 with respect to engineering education, engineering teacher education, links with the industry, envisaged role of professional associations in collaborating with institutes in the skill development of the engineering graduates and the growth of the polytechnic colleges.

\section{Research Questions}

The following are the research questions for the evaluation of the NEP 2019:

1. Whether the National Education Policy 2019 (draft) considers the contributions of four NITTTRs to Indian Engineering Education and Polytechnic Colleges through curriculum development, faculty development, assistance to State Directorates of Technical Education through dedicated Extension Centers, Interdisciplinary Research Works through Ph.D., in Engineering Education, Diverse Global Faculty Development under International Development Agencies, Academic Consultancy rendered to World Bank assisted projects in technician education (Tech Ed I, II, and III), TEQIP I and II, and Contribution to the Government Engineering Departments and to the Industries in the last 55 years?

2. Whether the Draft NEP 2019 focuses on the impact due to the trained polytechnic faculty and periodically revised curricula on the growth of industries in various regions of India?

3. Whether the draft NEP 2019 supports the formation of Engineering Education University?

4. Whether the needed linkages of NITTTRs with the engineering colleges/ state technical universities are focused similar to that of NIEPA/NUEPA?

5. Whether the draft NEP 2019 compared the contribution to the Technical Manpower with that of NCERT?

6. Whether the draft NEP 2019 compared the contribution of Polytechnic Colleges with that of Vocational Institutes? 
7. Whether the draft NEP 2019 would support the formation of National University in Engineering Education in the near future?

8. Whether the draft NEP 2019 contemplates the needed outstanding faculty with multidisciplinary skills in engineering and engineering education?

9. Whether the shortages in skills and competencies of the engineering graduates to meet the fast- growing digital technology disruptions are identified by the draft NEP 2019 ?

10. Whether the NEP 2019 demands the assessment of the needed technicians, engineers, and researchers through economic methods of forecasting?

11. Whether the needs for a multidisciplinary national institution for developing needed faculty development for state engineering colleges, curriculum evaluation, preparing outstanding outcome based undergraduate, postgraduate and research programs to meet the global challenges of Indian industries has been envisaged by the draft NEP 2019?

12. Whether the role of National Institute of Labour Economic Research and Development (NILERD/IAMR) has been envisaged to expand the engineering institutes?

13. Whether the role of professional associations like Indian Society for Technical Education (ISTE), Indian Institute for Training and Development (ISTD), Institution of Engineers (India) (IE), Indian Geotechnical Society (IGS), etc. are recognized for their contributions to the advancement of knowledge capital, faculty development etc. by the Draft NPE 2019?

14. Whether the need for Institute-IndustryGovernment- Community Partnership has been recognized?

15. Whether the role four Boards of Apprenticeship Training for training the engineers have been recognized in training the engineering and nonengineering graduates?

16. Whether the extended roles of Type-I universities have been recognized to become entrepreneur universities in developing intellectual properties, and creating link with the industries and entrepreneurs by incubation, pilot studies and collaborative research projects?

17. Whether NITTTRs can become standalone universities?

18. Can we move engineering education into multidisciplinary colleges and universities as per NPE 2019 (P15.2 Page 285)?
19. Can we establish departments of engineering education in universities ( $\mathrm{P}$ 15. 3.1-Page 288)

20. Who are the faculty in teacher education (pP5.3.3 p 289)?

21. Can we plan 4- year B. Tech. Ed programs (P15.3.2. p 289)?

22.Can we plan online engineering teacher education (P15.3. 4. p 289)?

23. Can we develop research-based engineering teacher preparation (P15.3.5 p 289)?

24.Can we establish interdepartmental collaboration for special subject? (P15.3.6p290)

25.Can we plan post-graduate and doctoral programs in engineering education? (P15.3.7 p 290)?

\section{Research Methodology}

1. Adopt critical appraisal of the proposed Draft NEP 2019 and compare with the existing provisions of NEP 1986 and revised NEP 1996.

2. Use the process of policy analyses,

suggest needed policy improvements which can be used for funding the professional growth of the faculty, graduates, industry specific multidisciplinary research programs in engineering education.

\section{Comparison of Polytechnic Colleges and Vocational Institutes}

The policy document provided more importance to vocational education and totally neglected the growth of polytechnic colleges which come under MHRD.

Table-1

\begin{tabular}{|l|l|l|}
\hline Issues & $\begin{array}{c}\text { Polytechnic } \\
\text { Colleges }\end{array}$ & $\begin{array}{c}\text { Industry } \\
\text { Vocational } \\
\text { institutes }\end{array}$ \\
\hline Curriculum & $\begin{array}{l}\text { Not focused on } \\
\text { the jobs. }\end{array}$ \\
\hline Entry level Jobs & $\begin{array}{l}\text { Middle level } \\
\text { supervisors in } \\
\text { industry }\end{array}$ & $\begin{array}{l}\text { Not defined } \\
\text { but skilled } \\
\text { jobs. }\end{array}$ \\
\hline $\begin{array}{l}\text { Contribution to } \\
\text { industrial needs }\end{array}$ & $\begin{array}{l}\text { Substantial } \\
\text { Recognition }\end{array}$ & Yet to stabilize \\
\hline Further growth & $\begin{array}{l}\text { Lateral entry } \\
\text { into B. E/ B. } \\
\text { Tech }\end{array}$ & $\begin{array}{l}\text { It is yet to be } \\
\text { recognized. }\end{array}$ \\
\hline Entrepreneurship & $\begin{array}{l}\text { Approves the } \\
\text { curriculum, } \\
\text { funds faculty } \\
\text { training, } \\
\text { provided funds }\end{array}$ & ot connected \\
\hline AICTE &
\end{tabular}




\begin{tabular}{|c|c|c|}
\hline & $\begin{array}{l}\text { for } \\
\text { modernization. }\end{array}$ & \\
\hline Accreditation & NBA & Unknown \\
\hline MHRD & $\begin{array}{l}\text { Developed } \\
\text { through World } \\
\text { Bank assisted } \\
\text { projects. }\end{array}$ & Nil \\
\hline $\begin{array}{l}\text { Controlling } \\
\text { Organization }\end{array}$ & $\begin{array}{ll}\text { Trectorate of } \\
\text { Technical } \\
\text { Education }\end{array}$ & NCERT \\
\hline $\begin{array}{l}\text { National Institute of } \\
\text { Labour Economic } \\
\text { Research and } \\
\text { Development } \\
\text { (NILERD/ IAMR) }\end{array}$ & $\begin{array}{l}\text { Should } \\
\text { continuously } \\
\text { conduct } \\
\text { research and } \\
\text { publish } \\
\text { forecasting. }\end{array}$ & $\begin{array}{l}\text { Conduct sector } \\
\text { specific } \\
\text { research } \\
\text { based on the } \\
\text { States } \\
\text { funding }\end{array}$ \\
\hline \begin{tabular}{l}
\multicolumn{1}{c}{ Board of } \\
Apprenticeship \\
Training (BOAT)
\end{tabular} & $\begin{array}{l}\text { Arranges on the } \\
\text { job training }\end{array}$ & $\begin{array}{ll}\text { Arranges } & \text { on } \\
\text { the } & \text { job } \\
\text { training } & \\
\end{array}$ \\
\hline Competitors & $\begin{array}{l}\text { Engineers, } \\
\text { AMIEs, \& } \\
\text { post- diploma } \\
\text { holders. }\end{array}$ & $\begin{array}{l}\text { dustrial } \\
\text { Training } \\
\text { Institutes and } \\
\text { Apprentice } \\
\text { trainees. }\end{array}$ \\
\hline
\end{tabular}

The above table shows the contribution of polytechnics to the industries.

\section{Faculty Development}

The faculty development by Academic Staff Colleges and NCERT have been considered but the performance and the future growth of NITTTRs have been omitted.

Table-2

\begin{tabular}{|c|c|c|}
\hline $\begin{array}{l}\text { Development } \\
\text { channels }\end{array}$ & $\begin{array}{l}\text { Polytechnic } \\
\text { faculty }\end{array}$ & $\begin{array}{l}\text { Vocational } \\
\text { faculty }\end{array}$ \\
\hline $\begin{array}{l}\text { Professional } \\
\text { Training }\end{array}$ & NITTTRs & NCERT \\
\hline $\begin{array}{l}\text { Professional } \\
\text { Association }\end{array}$ & ISTE & NIL \\
\hline AICTE & $\begin{array}{l}\text { Summer and } \\
\text { winter schools }\end{array}$ & NCERT \\
\hline $\begin{array}{l}\text { Long-term Faculty } \\
\text { Development } \\
\text { Programs }\end{array}$ & $\begin{array}{l}\text { B.E and M.E } \\
\text { programs of the } \\
\text { engineering } \\
\text { colleges }\end{array}$ & Unknown \\
\hline $\begin{array}{l}\quad \text { PhD., in } \\
\text { Engineering } \\
\text { education }\end{array}$ & $\begin{array}{l}\text { Polytech faculty } \\
\text { have completed } \\
\text { this } \\
\text { interdisciplinary } \\
\text { research } \\
\text { program. }\end{array}$ & Not applicable \\
\hline
\end{tabular}

Polytech faculty have been trained to create around 150 industry relevant programs through polytechnics. These institutes can be compared to Community Colleges of USA or Canada.
Faculty Development for Engineering College Faculty

Table-3

\begin{tabular}{|l|l|}
\hline Areas of Training & $\begin{array}{l}\text { Faculty of Engineering } \\
\text { Colleges }\end{array}$ \\
\hline Content updating & $\begin{array}{l}\text { IITs, NITs, Academic } \\
\text { Staff Colleges }\end{array}$ \\
\hline Andragogy & NITTTRs \\
\hline Masters and Ph.D. & $\begin{array}{l}\text { Autonomous Colleges, } \\
\text { State Technical } \\
\text { Universities, NITs, IITs }\end{array}$ \\
\hline $\begin{array}{l}\text { Educational methods, } \\
\text { Institutional Evaluation, } \\
\begin{array}{l}\text { Development } \\
\text { Transformation, and } \\
\text { Interdisciplinary } \\
\text { M. Tech. Ed., M. Tech. } \\
\text { (HRD), and Ph.D., } \\
\text { postgraduate programs } \\
\text { and Ph.D. }\end{array}\end{array}$ \\
\hline
\end{tabular}

The Engineering College faculty have been included based on the recommendation of Bhattacharya Committee (1991).

\section{Envisaged Engineering Teacher Education by NEP 2019 under Chapter 15 Teacher Education}

The suggested faculty development programs are presented in Table-4.

\section{Table-4}

Interdisciplinary Faculty Development Programs

\begin{tabular}{|c|c|}
\hline Suggested Program & User Institutions \\
\hline $\begin{array}{l}\text { Integrated Bachelor's } \\
\text { Degree }\end{array}$ & $\begin{array}{l}\text { School Education, should } \\
\text { replace low quality } \\
\text { commercial programs }\end{array}$ \\
\hline $\begin{array}{l}\text { High quality teacher } \\
\text { education system through } \\
\text { Strong Education } \\
\text { Department in } \\
\text { multidisciplinary } \\
\text { colleges and universities }\end{array}$ & $\begin{array}{l}\text { No university is having } \\
\text { multidisciplinary } \\
\text { engineering teacher } \\
\text { education. NITTTRs are } \\
\text { offering needed courses } \\
\text { through their faculty } \\
\text { members. }\end{array}$ \\
\hline $\begin{array}{l}\text { Moving engineering } \\
\text { teacher education into } \\
\text { multidisciplinary } \\
\text { colleges and universities } \\
\text { (P.15.2) }\end{array}$ & $\begin{array}{l}\text { Except NITTTRs no } \\
\text { other institution/ } \\
\text { university } \\
\text { institutionalized } \\
\begin{array}{l}\text { engineering teacher } \\
\text { education. }\end{array}\end{array}$ \\
\hline $\begin{array}{l}\text { Moving all teacher } \\
\text { preparation programs into } \\
\text { multidisciplinary } \\
\quad \text { Higher Education } \\
\text { institutions; building } \\
\text { education departments } \\
\text { and connections between } \\
\text { HEI and schools/school } \\
\text { complexes. }\end{array}$ & $\begin{array}{l}\text { Even IITs, NITs and State } \\
\text { Technical Institutes } \\
\text { depend on NITTTRs for } \\
\text { their teacher training. } \\
\text { Under TQEIP, } \\
\text { NITTTRs assisted the } \\
\text { state technical } \\
\text { universities and NITs in } \\
\text { planning detailed project } \\
\text { proposals and faculty } \\
\text { development. }\end{array}$ \\
\hline
\end{tabular}




\begin{tabular}{|l|l|}
\hline To this end, & ITTTRs are the only \\
multidisciplinary higher & institutes in India which \\
educational institutes will & can offer these \\
work towards & multidisciplinary \\
establishing high quality & postgraduate programs, \\
education departments & planning global diverse \\
and teacher education & faculty development \\
programs, and will be & programs, bidding and \\
supported by & winning global faculty \\
governments as necessary & development programs \\
to achieve the goal. & under IDAs. The need to \\
& be nurtured. They are all \\
& well recognized global \\
institutes.
\end{tabular}

The accomplishments of NITTTR Chennai prove that the Institute is pioneer in engineering faculty development.

Setting up Departments of Education for preparing faculty for professional education ( $P$ 16.4.1) According to NEP 2019: "In order to strengthen teacher education in the professional streams, Departments of Education will be set up, if they don't exist, at all universities that affiliate colleges offering professional education in any discipline. It is expected that these universities will eventually evolve into multidisciplinary HEIs. These Departments of Education will develop curriculum for teacher education in the respective professions and offer at Master's degree in Teaching and Research, which will be mandatory qualification for all aspiring teachers, to be taken besides a master degree in their subject specialization. The course will orient aspiring teachers and practitioners on curriculum development, pedagogy, assessment techniques etc., and will be delivered in the part-time, blended, or online mode to enable access to working professionals".

\section{Contributions of NITTTR-Chennai since 1964}

- Short-term courses based on the expressed needs of the State directorates.

- Offered Dip. T.T., Dip. Sc., B. Tech. Ed., Cert. T.T, and Cert. E.T courses for Engineering Teachers.

- Established extension centers in Andhra Pradesh, Karnataka, Kerala, and Telangana for offering faculty development programs and assistance in planning state specific curricula.

- Offered interdisciplinary M. Tech. (HRD), M. Tech. Ed, programs to Engineering Faculty members.

- Offered multidisciplinary research leading to $\mathrm{Ph} . \mathrm{D}$. in engineering education to the preservice teachers, in-service teachers, fresh graduates, and part-time candidates.

- Around 100 research scholars earned Ph.D. in the multidiscipline.
- Around 1500 diverse global participants have undergone professional development programs through various sponsoring organizations.

- Assisted the states to plan detailed project preparation for assistance from World Bank.

- Offered short-term courses in Curriculum Design, Instructional Materials Development, Measurement and Evaluation, Institutional Development and Transformation, Higher Education Management, Student Personnel Administration, planning diverse global faculty development, bidding for global projects under IDAs, establishing consultancy centers, establishing publication centers, etc.

- Conducted national and international seminars and conferences on Globalization and Networking of the Engineering Education.

- Undertook academic consultancy under World Bank assisted projects.

- Successfully completed faculty development projects under Asian Development Bank, DANIDA, GIZ, SIDA, UNDP, UNESCO, USAID, and World Bank.

- Prepares MOOCs in collaboration with other NITTTRs.

\section{Problems Faced}

- Slow approval of innovative programs by the affiliating university

- Most of the CEOs are not specialists in Engineering Education, interdisciplinary research, curriculum development, etc.

\section{Suggestions from Research and their Reflection in NEP 2019}

Table-5 Area-1 [Governance, Performance Management, Desired Educational Ecosystem, Institutional Transformation, Quality Assurance, Industry- Institute-Government Partnership, and Autonomy to High Performing Faculty Teams].

\begin{tabular}{|l|l|}
\hline $\begin{array}{l}\text { Suggestion made by the } \\
\text { author }\end{array}$ & $\begin{array}{l}\text { Reflection on the NPE } \\
\mathbf{2 0 1 9}\end{array}$ \\
\hline $\begin{array}{l}\text { Enhancing Institutional } \\
\text { Governance beyond the } \\
\text { Society's Act of 1860 (Steps }\end{array}$ & $\begin{array}{l}\text { Chapter 17: P 310: } \\
\text { "Empowered }\end{array}$ \\
$\begin{array}{l}\text { Governance Improve Autonomous } \\
\text { effective leadership for } \\
\text { Institute's Administration } \\
\text { higher of education } \\
\text { through Board of } \\
\text { Governors) [19]. }\end{array}$ & $\begin{array}{l}\text { P17.1 9 (page 311) } \\
\text { "Each higher education }\end{array}$ \\
& $\begin{array}{l}\text { institution will be } \\
\text { governed by an } \\
\text { independent Board- } \\
\text { this will ensure a clear } \\
\text { chain of responsibility } \\
\text { and accountability } \\
\text { within". }\end{array}$ \\
\hline
\end{tabular}




\begin{tabular}{|c|c|}
\hline & $\begin{array}{l}\text { Chapter 18: p18.6.4 } \\
\text { 'rinciples of good } \\
\text { governance". }\end{array}$ \\
\hline $\begin{array}{l}\text { Educational Management } \\
\text { Ecosystem for Facilitating } \\
\text { the Development of } \\
\text { Professional Competence in } \\
\text { CEOs in Higher Education } \\
\text { Institutions [25]. }\end{array}$ & 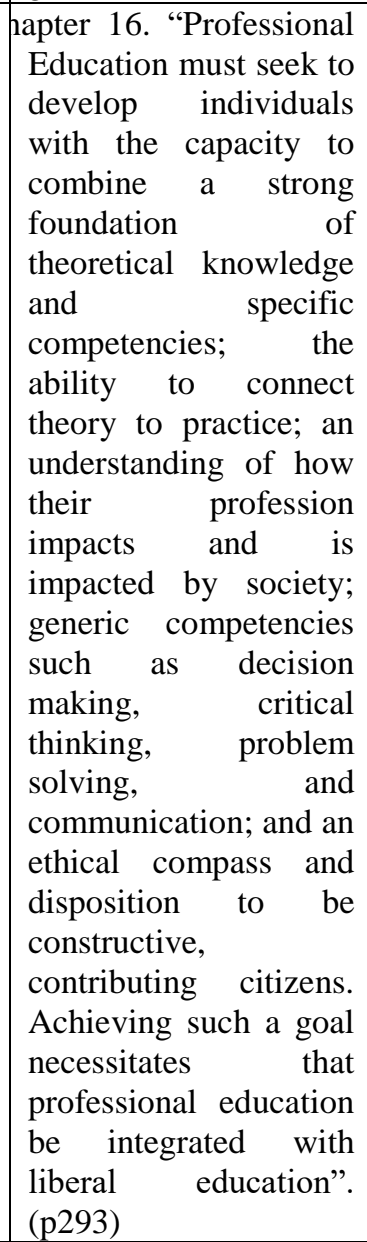 \\
\hline $\begin{array}{lr}\text { Performance } & \text { Management } \\
\text { and Turnaround Mechanism } \\
\text { of Poorly } & \text { Performing } \\
\text { Institutes [26]. } & \end{array}$ & $\begin{array}{l}.1 . \quad \text { "Empowered } \\
\text { governance and } \\
\text { effective leadership". }\end{array}$ \\
\hline \begin{tabular}{lrr}
\multicolumn{1}{c}{ Radical and } & Virtual \\
Innovation & Center for \\
Human & \multicolumn{2}{c}{ Resource } \\
Development $[40]$.
\end{tabular} & $\begin{array}{l}\text { Institutional governance } \\
\text { will be based on full } \\
\text { autonomy-academic, } \\
\text { administrative and } \\
\text { financial-for all higher } \\
\text { education institutions } \\
\text { with financial certainty } \\
\text { and backing" (p 312). }\end{array}$ \\
\hline $\begin{array}{c}\text { Model for Learning } \\
\text { Organization }[6,8] .\end{array}$ & $\begin{array}{l}\text { 17.1.14 "Continuous } \\
\text { professional } \\
\text { development for heads } \\
\text { of institutions and } \\
\text { others in leadership } \\
\text { roles". }\end{array}$ \\
\hline $\begin{array}{l}\text { Advanced Educational } \\
\text { System to Undertake } \\
\text { International Projects in the } \\
\text { Engineering Institutes under } \\
\text { Globalized Economy [28, } \\
\text { 1]. }\end{array}$ & $\begin{array}{l}\text { 10; "New institutional } \\
\text { architecture with large, } \\
\text { well-resourced, vibrant } \\
\text { multidisciplinary } \\
\text { institutions for teaching } \\
\text { and research, which } \\
\text { will be significantly }\end{array}$ \\
\hline
\end{tabular}

\begin{tabular}{|c|c|}
\hline & $\begin{array}{l}\text { expand reach and } \\
\text { capacity". }\end{array}$ \\
\hline $\begin{array}{l}\text { Need for Change Models for } \\
\text { Educational Organizations } \\
\text { in Higher Education in India } \\
\text { [11]. }\end{array}$ & $\begin{array}{l}\text { 10.1.a: } \mathrm{p} 212 . \text { "HEIs will } \\
\text { become } \\
\text { multidisciplinary } \\
\text { institutions". }\end{array}$ \\
\hline $\begin{array}{l}\quad \text { Desired } \\
\text { Ecosystem in the Fast- } \\
\text { Growing } \\
\text { Institutes in India [27]. }\end{array}$ & $\begin{array}{l}\text { 9. 3: "Moving towards } \\
\text { faculty and institutional } \\
\text { autonomy". (page: } 208 \text { ) }\end{array}$ \\
\hline $\begin{array}{l}\text { Institutional Transformation } \\
\text { and Development in the } \\
\text { Engineering Education to } \\
\text { meet Volatility, Uncertainty, } \\
\text { Complexity, and Ambiguity } \\
\text { (VUCA) [23]. }\end{array}$ & 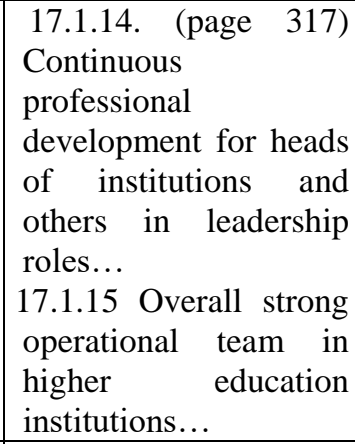 \\
\hline $\begin{array}{l}\text { Critical Reappraisal of } \\
\text { Leadership } \\
\text { Management Models in } \\
\text { Higher Education with a } \\
\text { Focus on Indian Scenario } \\
\text { [41]. }\end{array}$ & $\begin{array}{l}\text { 17.1: "Selection and } \\
\text { professional } \\
\text { development process } \\
\text { for those in institutional } \\
\text { leadership processes } \\
\text { for selection of people } \\
\text { in leadership needs to } \\
\text { be followed, with well- } \\
\text { defined guidelines for } \\
\text { each position need to } \\
\text { be followed, with well- } \\
\text { defined guidelines for } \\
\text { each position based on } \\
\text { the role and the } \\
\text { competencies required } \\
\text { for the role". }\end{array}$ \\
\hline $\begin{array}{l}\text { Comparative Study between } \\
\text { Affiliated Engineering } \\
\text { Colleges and Deemed } \\
\text { Universities [5]. }\end{array}$ & $\begin{array}{l}\text { Tier III colleges will be } \\
\text { formed. They can offer } \\
\text { degrees". }\end{array}$ \\
\hline $\begin{array}{l}\text { Institutional Design to } \\
\text { Support an Educational } \\
\text { Transformation } \\
\text { Engineering Colleges in } \\
\text { India [31]. }\end{array}$ & $\begin{array}{l}\text { 9.3: "Through faculty } \\
\text { autonomy, faculty will } \\
\text { be enabled and } \\
\text { motivated to innovate } \\
\text { in their teaching and } \\
\text { pedagogical } \\
\text { approaches, student } \\
\text { assessment, } \\
\text { community service } \\
\text { initiatives and research, } \\
\text { and share best practices } \\
\text { and ideas with each } \\
\text { other in university wide } \\
\text { and larger forums in } \\
\text { order to continuously } \\
\text { improve". }\end{array}$ \\
\hline
\end{tabular}




\begin{tabular}{|c|c|}
\hline $\begin{array}{l}\text { Building } \text { Organizational } \\
\text { Learning Capabilities in } \\
\text { Affiliated Polytechnics [8]. }\end{array}$ & $\begin{array}{l}\text { Polytechnics were not } \\
\text { considered. }\end{array}$ \\
\hline $\begin{array}{l}\text { Integrated Model for } \\
\text { Institutional Development to } \\
\text { Create Excellence in } \\
\text { Technical Education [31]. }\end{array}$ & $\begin{array}{l}\text { Chapter 17: "high } \\
\text { quality education and } \\
\text { research requires } \\
\text { intellectual ferment in a } \\
\text { culture-the governance } \\
\text { of higher education } \\
\text { institutions determines } \\
\text { the culture". }\end{array}$ \\
\hline $\begin{array}{l}\text { Global Convergence to } \\
\text { Improve the Internal Quality } \\
\text { Assurance for Postgraduate } \\
\text { Engineering Programs [16]. }\end{array}$ & Refer to 16.9 .2 \\
\hline $\begin{array}{l}\text { Strengthening and Sustaining } \\
\text { of Industry-Academies- } \\
\text { Government Partnership } \\
\text { Improvement [17]. }\end{array}$ & Refer to P 16.9.3. \\
\hline \begin{tabular}{lr}
\multicolumn{2}{c}{ Industry-Academia } \\
Interaction in $\begin{array}{r}\text { Engineering } \\
\text { Education }\end{array}$ \\
Professional \\
{$[32]$.}
\end{tabular} & $\begin{array}{l}\text { 16.9.3: "encouraging } \\
\text { industry interactions". }\end{array}$ \\
\hline $\begin{array}{lrr}\text { Transformation } & \text { in } & \text { Indian } \\
\text { Engineering } & \text { Education } \\
\text { through } & \text { Academic } \\
\text { Autonomy } & \text { to } r \text { High } \\
\text { Performing } & \text { Faculty } & \text { Teams } \\
{[21] .} & \end{array}$ & $\begin{array}{l}\text { 13.1 Putting faculty into } \\
\text { the heart of higher } \\
\text { education institutions: } \\
\text { motivating and } \\
\text { energizing to achieve } \\
\text { high quality in higher } \\
\text { education; ensuring } \\
\text { service conditions to } \\
\text { excellent teaching and } \\
\text { research; enabling } \\
\text { vibrant university } \\
\text { communities through } \\
\text { faculty empowerment; } \\
\text { incentivizing through } \\
\text { excellence creer } \\
\text { merit-based cared } \\
\text { management; creating } \\
\text { a culture of excellence } \\
\text { through outstanding } \\
\text { institutional leadership; } \\
\text { higher education } \\
\text { faculty must be valued } \\
\text { and supported with } \\
\text { excellent preparation } \\
\text { and conducive working } \\
\text { environments (page: } \\
\text { 258-59). }\end{array}$ \\
\hline $\begin{array}{l}\text { Strategies to Accelerate } \\
\text { Autonomy to High } \\
\text { Performing Institutes [10]. }\end{array}$ & $\begin{array}{lr}\text { 13.1.4: Institutional } \\
\text { Autonomy } r \text { for } \\
\text { Recruitment. P13.1.5: } \\
\text { Empowering } \\
\text { motivating institutional } \\
\text { culture. P } & \text { 13.1.6: } \\
\text { Permanent } & \end{array}$ \\
\hline
\end{tabular}

\begin{tabular}{|c|l|}
\hline & $\begin{array}{l}\text { employment track for } \\
\text { university staff }\end{array}$ \\
\hline $\begin{array}{c}\text { Impact of Project } \\
\text { Polytechnics on the States } \\
{[42,43,44] .}\end{array}$ & \\
\hline $\begin{array}{c}\text { Impact of World Bank } \\
\text { assisted Project on North } \\
\text { Eastern States [42, 43, 44]. }\end{array}$ \\
\hline
\end{tabular}

NEP 2019 has been well prepared to solve many problems in educational administration, management and faculty selection and autonomy. The research outcomes are well reflected in the NEP 2019.

Table-6 Curriculum Planning

\begin{tabular}{|c|c|}
\hline $\begin{array}{l}\text { Suggestion made by the } \\
\text { author }\end{array}$ & $\begin{array}{l}\text { Reflection on the } \\
\text { NEP 2019 }\end{array}$ \\
\hline $\begin{array}{l}\text { An integrated curriculum } \\
\text { model for three-year } \\
\text { diploma program in civil } \\
\text { engineering [7]. }\end{array}$ & $\begin{array}{l}\text { 9.4 Curriculum, } \\
\text { pedagogy, } \\
\text { assessment, } \\
\text { student support } \\
\text { be revamped. }\end{array}$ \\
\hline $\begin{array}{l}\text { An integrated model for } \\
\text { instructional design and } \\
\text { delivery in Engineering } \\
\text { Programs [12]. }\end{array}$ & $\begin{array}{l}\text { 16.9.1: Curricula must } \\
\text { be renewed with a } \\
\text { focus on opportunities } \\
\text { to engage deeply with } \\
\text { the field and be more } \\
\text { inclusive of other } \\
\text { disciplines. }\end{array}$ \\
\hline $\begin{array}{l}\text { Curriculum design for } \\
\text { industry relevant and } \\
\text { interdisciplinary } \\
\text { postgraduate programs in } \\
\text { engineering } \\
\text { technology [15]. }\end{array}$ & \begin{tabular}{lr}
\multicolumn{1}{c}{ 16.9.2: } & "Indian \\
National Academy of \\
Engineering & (INAE) \\
will & devise \\
appropriate & \\
curricula." (p308).
\end{tabular} \\
\hline 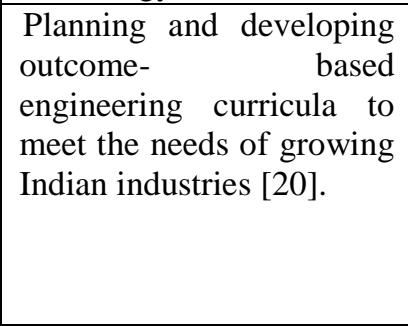 & $\begin{array}{l}\text { 12.1: Innovative and } \\
\text { responsive } \\
\text { curriculum and } \\
\text { pedagogy (page 241). } \\
\text { P12.1.2: } \\
\text { Development of } \\
\text { vibrant and rigorous } \\
\text { curricula. }\end{array}$ \\
\hline $\begin{array}{l}\text { Narrowing the gap between } \\
\text { engineering education and } \\
\text { industry through science, } \\
\text { technology, economics, } \\
\text { management and fire- } \\
\text { fighting [45]. }\end{array}$ & $\begin{array}{l}\text { 16.9.3: Encouraging } \\
\text { Industry Interactions: } \\
\text { Industry-academic } \\
\text { collaborations, b) } \\
\text { appointing faculty } \\
\text { with research and } \\
\text { industry experience, } \\
\text { c) industry experts } \\
\text { on boards of studies, } \\
\text { d) internships, e) } \\
\text { sharing state of art } \\
\text { resources }\end{array}$ \\
\hline $\begin{array}{l}\text { Critical reviews of selected } \\
\text { postgraduate programs in } \\
\text { transportation engineering } \\
\text { against the needs of the }\end{array}$ & \begin{tabular}{|lr}
\multicolumn{1}{|c}{ 12.1.3: } & National \\
frameworks & for \\
learning & goals \\
(NHEQF); & P12.1.4:
\end{tabular} \\
\hline
\end{tabular}




\begin{tabular}{|l|lr|}
\hline $\begin{array}{l}\text { infrastructure development } \\
{[24] .}\end{array}$ & $\begin{array}{l}\text { Stimulating learning } \\
\text { experiences through } \\
\text { effective teaching and } \\
\text { learning and } \\
\text { pedagogical } \\
\text { resources. }\end{array}$ \\
\hline $\begin{array}{l}\text { Valid and reliable grading } \\
\text { and evaluation system in } \\
\text { engineering education } \\
{[29] .}\end{array}$ & $\begin{array}{l}\text { development and not } \\
\text { judgement; P. 12.1.7: } \\
\text { Curriculum and } \\
\text { pedagogy to be } \\
\text { institutional and } \\
\text { assessment and } \\
\text { development. }\end{array}$ \\
\hline
\end{tabular}

In Curriculum planning, NEP suggests most appropriate methods. INAE may have sufficient faculty or experts to prepare curricula. The faculty needs more exposure to plan needed outcome- based curricula. All NITTTRs can take up as a national project.

Table-7 Entrepreneurship development

\begin{tabular}{|l|l|}
\hline $\begin{array}{l}\text { Suggestion made by } \\
\text { the author }\end{array}$ & $\begin{array}{l}\text { Reflection on the } \\
\text { NEP 2019 }\end{array}$ \\
\hline $\begin{array}{l}\text { Entrepreneurship and } \\
\text { Innovation } \\
\begin{array}{l}\text { Engineering } \\
\text { Education [18]. }\end{array}\end{array}$ & $\begin{array}{l}\text { Entrepreneurship has } \\
\text { been suggested. }\end{array}$ \\
\hline
\end{tabular}

There is a focus on entrepreneurship development.

Table -8 Faculty Development

\begin{tabular}{|c|c|}
\hline $\begin{array}{l}\text { Suggestion made by } \\
\text { the author }\end{array}$ & $\begin{array}{l}\text { Reflection on the NEP } \\
2019\end{array}$ \\
\hline $\begin{array}{l}\text { Lecturer induction and } \\
\text { mentoring program } \\
{[14] \text {. }}\end{array}$ & $\begin{array}{l}\text { 13.1.8. } \\
\text { program for } \\
\text { faculty }(\mathrm{p} 261) .\end{array}$ \\
\hline Development of & 16.4.1 (page 299). \\
\hline $\begin{array}{l}\text { NITTTR as a World } \\
\text { Class Institute to } \\
\text { provide services under } \\
\text { GATS [9]. }\end{array}$ & $\begin{array}{l}\text { Setting up departments } \\
\text { of Education for } \\
\text { preparing faculty for } \\
\text { professional education. }\end{array}$ \\
\hline \begin{tabular}{lr}
$\begin{array}{l}\text { Improving } \\
\text { Performance }\end{array}$ & $\begin{array}{c}\text { Faculty } \\
\text { through }\end{array}$ \\
Effective & Human \\
Resource Management \\
\multicolumn{2}{l}{ Practices [46]. }
\end{tabular} & $\begin{array}{l}\quad \text { Universities will } \\
\text { eventually evolve into } \\
\text { multidisciplinary } \\
\text { HEIs. }\end{array}$ \\
\hline $\begin{array}{l}\text { Dynamic process for } \\
\text { enhancing engineering } \\
\text { faculty competence in } \\
\text { India [30]. }\end{array}$ & $\begin{array}{l}\text { Departments of } \\
\text { education will develop } \\
\text { curriculum for the } \\
\text { teacher education and } \\
\text { offer the Master's } \\
\text { degree in teacher } \\
\text { education and research } \\
\text { which will be } \\
\text { mandatory } \\
\text { qualification besides a } \\
\text { Master's degree in } \\
\text { their subject } \\
\text { specialization. }\end{array}$ \\
\hline
\end{tabular}

\begin{tabular}{|c|c|}
\hline $\begin{array}{l}\text { Contributions to diverse } \\
\text { engineering faculty and } \\
\text { to the South Asian } \\
\text { Regional Development } \\
\text { [33]. }\end{array}$ & $\begin{array}{l}\text { Internationalization of } \\
\text { higher education; p } \\
\text { 12.4.1: Internationally } \\
\text { relevant education }\end{array}$ \\
\hline $\begin{array}{l}\text { Strategies for promoting } \\
\text { globally competitive } \\
\text { engineering education } \\
\text { in India [35]. }\end{array}$ & $\begin{array}{l}\text { 12.4.3: Encouraging } \\
\text { institutional } \\
\text { collaborations; } P \\
\text { 12.4.6 Ptudent } \\
\text { exchange }\end{array}$ \\
\hline $\begin{array}{l}\text { Strategies for self- } \\
\text { regulated learning by } \\
\text { engineering students } \\
\text { [37]. }\end{array}$ & $\begin{array}{l}\text { 12.1.5: Meaningful } \\
\text { opportunities for all } \\
\text { social engagement for } \\
\text { all students in higher } \\
\text { education. }\end{array}$ \\
\hline
\end{tabular}

The Focus on faculty development is sufficient. It is hoped that the CEOs would sincerely follow the suggestions of NPE 2019. Globalization of higher education has been focused very well.

Table -9 Interdisciplinary Research in Engineering Education

\begin{tabular}{|c|c|}
\hline $\begin{array}{l}\text { Suggestion made by the } \\
\text { author }\end{array}$ & $\begin{array}{l}\text { Reflection on the NEP } \\
2019\end{array}$ \\
\hline $\begin{array}{l}\text { Enhancing } \\
\text { Interdisciplinary Research } \\
\text { in Engineering Education } \\
\text { (IRDEE) [48]. }\end{array}$ & $\begin{array}{l}16.3 \text { "Postgraduate } \\
\text { education and } \\
\text { research. Post- } \\
\text { graduate education in } \\
\text { the professional } \\
\text { streams need to be } \\
\text { strengthened } \\
\text { considerably". }\end{array}$ \\
\hline $\begin{array}{l}\text { Narrowing the gaps } \\
\text { between } \\
\text { education and industry } \\
\text { [45]. }\end{array}$ & $\begin{array}{l}\text { The curriculum must } \\
\text { ensure that post- } \\
\text { graduates acquire } \\
\text { knowledge, skills, } \\
\text { self-confidence and } \\
\text { entrepreneurship } \\
\text { training, to enable } \\
\text { them to contribute to } \\
\text { social and national } \\
\text { productivity" (p298). }\end{array}$ \\
\hline \begin{tabular}{l}
\multicolumn{1}{c}{ Research cluster in } \\
engineering education and \\
human resource \\
development [22].
\end{tabular} & $\begin{array}{l}\text { 16.9.2: Strategic trust } \\
\text { on new and emerging } \\
\text { disciplines in } \\
\text { professional } \\
\text { education. }\end{array}$ \\
\hline
\end{tabular}

\section{Upgrading NITTTRs as Tier I University}

As per the suggestions of NPE 2019, NITTTRs have to be upgraded into multidisciplinary research university in Engineering Education, Research, training diverse global participants under IDAs and Bi lateral schemes of Government of India, offering consultancy to industries, and other universities. 
This does not a standalone university. It will provide more academic consultancy to various professional development programs. These multidisciplinary universities would offer professional guidance to vocational institutes and NCERT.

\section{Contribution}

The following gaps need to be closed:

1.Future growth of NITTTRS. 2. Inclusion of Polytechnic Colleges in the NEP 20193.

3. Growth of Tier III Universities into Entrepreneurial Universities,

4. Role of Boards of Apprenticeship Training, 5. Active role of Government in linking industries and the engineering institutes.

\section{Implication}

1. If the gaps are not closed, the skills and competencies of the engineering faculty members, and the graduates would be very much affected.

2. If there is no focus on NITTTRs, these institutes will not be growing to meet the gaps between the fast-growing industry and the engineering institutes. They need to be classified into Tier I institutes which will focus on Human Resources Development, Andragogy, Learning and Cognition, Multimedia Programs, MOOCs, Hybrid Programs, Educational Technology, Advances in Educational Measurement and Evaluation, Higher Education Administration, Leadership Development, Institutional Development, Strategies for Managing VUCA, Educational Economics, Financial Management, ROI, Policy Analysis, Industry Linked Advanced Research Programs, Training and Developing the Executives of Industries, Entrepreneurship Development, Multidisciplinary Research Programs, Diverse Global Faculty Development, Student Personnel Administration, Cooperative and Part-time Vocational/ Engineering Education, Internal Revenue Generation and Utilization, Development and Publication of Learning Packages, Consultancy Centers in the Industrial Corridors and Hubs, etc.

3. The active government support alone will assist the growth institute- industry- societypartnership to solve the problems in human capital and knowledge capital.

4. Linking the Institute of Human Resource Development (Institute of Applied Manpower Research) with the engineering institutions for planning needed programs based on the realistic macro economy.

\section{Envisaged Roles of NITTTRs in the next 12 years as per NEP 2019}

Considering the contributions of NITTTRs, Table-10 provides the envisaged roles. Even if competitive bidding is envisaged these institutes would develop most desired proposals for implementing as they did for Asian Development Bank, GIZ, UNDP, UNESCO, USAD and World Bank.

Table 10 New Roles for NITTTRs

\begin{tabular}{|c|c|}
\hline $\begin{array}{cc}\text { NEP } & 2019 \\
\text { Suggestions } & \\
\end{array}$ & $\begin{array}{c}\text { Possible Proactive Steps that } \\
\text { can be taken by NITTTRs }\end{array}$ \\
\hline $\begin{array}{l}\text { Schools of Higher } \\
\text { Education (P10.4-p } \\
\text { 215); Development } \\
\text { of the new } \\
\text { institutional } \\
\text { architecture } \\
\text { (P10.5) } \\
\text { Central Government } \\
\text { funded higher } \\
\text { education to } \\
\text { institutions to } \\
\text { develop into Type-I } \\
\text { Institutions }\end{array}$ & $\begin{array}{l}\text { Plan Elective Courses on } \\
\text { Educational Planning, and } \\
\text { Management. } \\
\text { stitutional Evaluation and } \\
\text { Development. } \\
\text { Institutional Transformation. } \\
\text { Leadership Development. } \\
\text { Creating Centers of } \\
\text { Excellence } \\
\text { Student } \\
\text { Administration. Personnel } \\
\text { Interdisciplinary Curriculum } \\
\text { Planning and Design. } \\
\text { Industry-Institute- } \\
\text { Government-Society } \\
\text { Partnership. } \\
\text { Interdisciplinary Research. } \\
\text { ultimedia Learning Packages. }\end{array}$ \\
\hline $\begin{array}{l}\text { Chapter 12 Optimal } \\
\text { Learning } \\
\text { Environment and } \\
\text { Support for } \\
\text { Students. } \\
\text { P12.1 Innovative } \\
\text { and Responsive } \\
\text { curriculum and } \\
\text { pedagogy }\end{array}$ & $\begin{array}{l}\text { Creation of self- directed } \\
\text { learning. } \\
\text { Planning dual programs. } \\
\text { Research courses in the } \\
\text { undergraduate programs } \\
\text { Outcome based education. } \\
\text { Dissertations based on the } \\
\text { needs of MSMEs. } \\
\text { Andragogy in planning } \\
\text { instructional design. }\end{array}$ \\
\hline \begin{tabular}{|rr} 
P12.2. & Student \\
Support & for \\
learning & and \\
development. &
\end{tabular} & $\begin{array}{l}\text { Electives based on the } \\
\text { students' career needs. } \\
\text { Innovations focused learning } \\
\text { Learning and cognition based } \\
\text { on the human resource } \\
\text { dynamics }\end{array}$ \\
\hline P $12.3 \mathrm{ODL}$ & $\begin{array}{l}\text { Integration of MOOCs with } \\
\text { F2F Instructions }\end{array}$ \\
\hline $\begin{array}{r}12.4 \\
\text { Internationalization } \\
\text { of higher education }\end{array}$ & $\begin{array}{l}\text { Joint research projects, } \\
\text { Developing Diverse Global } \\
\text { Faculty } \\
\text { SPARK, GIAN. India-USA } \\
21^{\text {st }} \text { Century Knowledge } \\
\text { Initiatives }\end{array}$ \\
\hline
\end{tabular}




\begin{tabular}{|l|l|}
\hline 15.3 Departments of & Establishing \\
Education in the & multidisciplinary education \\
Universities. & departments; planning and \\
P15.5 Faculty in & conducting r faculty \\
Higher Education; & development. \\
P 16.9 Encouraging & \\
industry & \\
interactions. & \\
\hline 19.1 Setting up of a & NITTTRs can contribute to \\
New Educational & this forum. \\
Technology & \\
Forum. & \\
\hline
\end{tabular}

\section{Results and Discussions}

Indian engineering graduates have performed very well even in very demanding foreign culture and created a large number of patents and innovative products. Hence, there is an urgent need for focusing on the developing the NITTTRs as world class multidisciplinary universities so that they can contribute to the fast growth of not only to Indian industry, but also MNCs and TNCs. Unitary universities in Agriculture, Forestry, Animal Science, Fisheries, Law, Medicine, Sports, Music, Languages etc. have grown because of the decentralized knowledge development, empowerment, delegation. Under liberal arts university, they can't grow at all. The culture of liberal arts university is not conducive for specialization in India.

\section{Conclusion}

There is a need for a national debate and validation for improving the focus of Draft NPE 2019 and the growth of NITTTRs is to be ensured. This will provide more skilled and competent faculty members and engineering graduates.

There is need for validation of the NEP2019 by various educational subsystems. The validated NEP 2019 has to provide sector wise program of implementation for next 12 years.

The suggested funds are to be allocated for efficient and effective implementation.

\section{Acknowledgements}

The author acknowledges all the faculty members, and the administrators who provided this opportunity to evaluate NPE 2019.

\section{References}

Draft National Education Policy 2019. New Delhi: MHRD. GOI.

1. National Education Policy 1986, New Delhi: MHRD, GOI.
2. National Education Policy, Updated in 1992., New Delhi: MHRD, GOI.

3. National Educational Policy (Draft) 2019 [Kasturirangan, K. et al.] New Delhi: MHRD, GOI.

4. Sujatha. S and Thanikachalam. V. (2013). An Integrated Model for Institutional Development to Create Excellence in Technical Education, The Journal of Engineering and Technology Education, 6(2), 34-50.

5. Sujatha. S and Thanikachalam. V. (2013). A Comparative Study between Affiliated Engineering Colleges and Deemed Universities, Journal of Engineering and Technology Education, 7(1).

6. Swaminathan. S. (2010). A Model for Building Learning Organization, Indian Journal of Training and Development, 30(3), 72-82.

7. Thamilarasu. V. and Thanikachalam. V. (2004). A Critical Review of the Focus and Implementation of Three-Year Diploma in Civil Engineering in Affiliated Polytechnics, Indian Journal of Technical Education, 27(2), 104-112.

8. Thamilarasu. V. and Thanikachalam. V. (2004). Building Organizational Learning Capabilities in Affiliated Polytechnics, The Journal of Engineering Education, 18(1), 24-30.

9. Thanikachalam. V. (2004). Development of NITTTR as World Class Institute to Provide Services under GATS, New Frontiers in Education, 34 (3).

10. Thanikachalam. V. (2005). Strategies to Accelerate Autonomy to High Performing Institutions, New Frontiers in Education, 35(1), 14-28.

11. Thanikachalam. V. (2005). Need for Changes in Models for Educational Organizations in Higher Education, Persfectives in Higher Education, 21(4), 216-225.

12. Thanikachalam. V. (2005). Integrated Model for Instructional Design and Delivery in Engineering Programs, The Indian Journal of Technical Education, 28(2), 24-37.

13. Thanikachalam. V. (2005). A Critical Reappraisal of Leadership and Management Models in Higher Education with a Focus on Indian Scenario, New Frontiers in Education, 36 (1).

14. Thanikachalam. V. (2005). Lecturer Induction and Mentoring Program, Journal of Engineering Education Transformations, 19(2), DOI:10.16920/jeet/2005/v1912/114801

15. Thanikachalam. V. (2015). Curriculum Design for Industry Relevant and Interdisciplinary Postgraduate Programs in Engineering and 
Technology, Journal of Engineering Education Transformations, Special Issue, January 2015., DOI: $10.16920 /$ jeet/2015/v0i0/59458

16. Thanikachalam. V. (2015). Global Convergence to Improve Quality Assurance for Post Graduate Engineering Programs, Journal of Engineering Education Transformations, Special Issue, January 2015, DOI: 10.16920/jeet/2015/v0i0/59343

17. Thanikachalam. V. (2016). Strengthening and Sustaining of Industry-AcademicsGovernment- Partnership through Continuous Process Improvement, Journal of Engineering Education Transformations, Special Issue, 2016., DOI: 10.16920/jeet/2016/v0i0/85436

18. Thanikachalam. V. (2016). Intrapreneurship and Innovation in Engineering Education, Journal of Engineering Education Transformations, 29(3), DOI: 10.16920/jeet/2016/v29i3/85204

19. Thanikachalam. V. (2016). Enhancing Institutional Governance Beyond the Society's Act of 1860 (Steps to Improve Autonomous Institute's Administration through Board of Governors), Journal of Engineering Education Transformations, Special Issue, 2016, DOI: 10.16920/jeet/2016/v0i0/85534

20.Thanikachalam. V. (2016). Planning and Developing Outcome-based Engineering Curricula to meet the Needs of Fast- Growing Indian Industries., Journal of Indian Engineering Education Transformations, 30(1), DOI: $10.16920 /$ jeet/2016/v30i1/97426

21. Thanikachalam. V. (2016). Transformation in Indian Engineering Education through Academic Autonomy to High Performing Faculty Teams, Journal of Engineering Education Transformations, 30(1), DOI: 10.16920/jeet/2016/v30i1/85435

22. Thanikachalam. V. (2017). Research Cluster in Engineering Education and Human Resource Development, Journal of Engineering Education Transformations, Special Issue 2017, DOI: $10.16920 /$ jeet/v0i0/111750

23. Thanikachalam. V. (2018). Institutional Transformation and Development in the Engineering Education to meet the Volatility, Uncertainty, Complexity and Ambiguity (VUCA), Journal of Engineering Education Transformations, Special Issue, 2018, DOI: 10. 16920/jeet/2018/v0i0/120895

24. Thanikachalam. V. (2018). Critical Reviews of Selected Postgraduate Programs in Transportation Engineering against the Needs of Infrastructure Development, Journal of
Engineering Education Transformations, 31(4)., DOI: 10.16920/jeet/2018/v31i4/125198

25. Thanikachalam. V. (2018). Educational Management Ecosystem for Facilitating the Development of Professional Competence in CEOs in Higher Education Institutes. Fifth International conference in Transformations on Indian Engineering Education, Madurai: Theagarajar College of Engineering, India.

26. Thanikachalam. V. (2018). Performance Management and Turnaround Mechanism of Poorly Performing Institutes, Journal of Engineering Education Transformations, 32(2), DOI: $10.16920 /$ jeet/2018/v32i2/139500

27. Thanikachalam. V. (2018). Desired Ecosystem in the Fast-Growing Educational Institutes in India, AP-IUCTIEE. Amaravati-AP: SRM University

28. Thanikachalam. V. (2018). Advanced Educational System to Undertake International Projects in the Engineering Institutes under Globalized Economy, AP-IUCTIEE. Amaravati-AP: SRM University

29. Thanikachalam. V. (2018). Valid and Reliable Grading and Evaluation System in Engineering Education, AP-IUCTIEE. Amaravati-AP: SRM University

30. Thanikachalam. V. (2018). Dynamic Process for Enhancing Engineering Faculty Competence in India. AP-IUCTIEE. Amaravati. AP: SRM University

31. Thanikachalam. V. (2018). Institutional Design to Support an Educational Transformation in the Engineering Colleges in India. APIUCTIEE. Amaravati: SRM University

32. Thanikachalam. V. (2018). Industry Academia Interaction in Engineering Education through Professional Association. Sixth International Conference on Transformation in Indian Engineering Education. Hyderabad: Malla Reddy Engineering College.

33. Thanikachalam. V. (2018). Contribution to Diverse Engineering Faculty and South Asian Regional Development- A Case Study. Sixth International Conference on Transformation in Indian Engineering Education. Hyderabad: Malla Reddy Engineering College.

34. Thanikachalam. V. (2018). Innovative Methods in the Evaluation of Postgraduate Courses. Sixth International Conference on Transformation in Indian Engineering Education. Hyderabad: Malla Reddy Engineering College.

35. Thanikachalam. V. (2018). Strategies for Promoting Globally Competitive Engineering Education in India. Sixth International 
Conference on Transformation in Indian Engineering Education. Hyderabad: Malla Reddy Engineering College.

36. Thanikachalam. V. (2018). Role of Heads of Indian Engineering Colleges in Implementing Digital Technology based Programs. Sixth International Conference on Transformations in Indian Engineering Education. Hyderabad: Malla Reddy Engineering College

37. Thanikachalam. V. (2018). Effects of SelfRegulated Learning Strategies on Engineering Education. Sixth International Conference on Transformations in Indian Engineering Education. Hyderabad: Malla Reddy Engineering College.

38. Thanikachalam. V. (2019). Desired Educational System in the Fast-Growing Educational Institutes in India. Journal of Engineering Education Transformations, 3294). DOI: $10.16920 /$ jeet/2019/v32i4/145513

39. Thanikachalam. V. (2019) Impact of Corrutocracy on High Performing Faculty in Engineering. Monograph.

40. Thanikachalam. V. (2019). A Radical and Virtual Innovation Center for Human Resource Development. Monograph.

41. Thanikachalam. V. (2019). How can the Universities Improve the Faculty Performance through Effective Human Resource Management Practices? Monograph.

42. Thanikachalam. V. and Theagarajan. R. (2008). Impact of World Bank Assisted Technician Education Project III on Meghalaya State. Noida: National Project Implementation Unit,

43. Thanikachalam. V. and Theagarajan. R. (2008). Impact of World Bank Assisted Technician Education Project III on Mizoram State. Noida: National Project Implementation Unit.

44. Thanikachalam. V. and Theagarajan. R. (2008). Impact of World Bank Assisted Project III on Tripura State. Noida: National Project Implementation Unit.

45. Thanikachalam. V (2019). Synthesis of Narrowing the Gap between Engineering Education and Industry through Science, Technology, Economics, Management and Fire Fighting. Monograph.

46. Thanikachalam. V. (2019) How can the Universities Improve the Faculty Performance through Effective Human Resource Management Practices? Monograph.

47. Thanikachalam. V. (2018). Strategies for Eliminating Corruption in Engineering Education and Fostering Excellence in Human Capital Development. Fifth International Conference on Transformations in Indian
Engineering Education. Madurai: Theagarajar College of Engineering. India.

48. Thanikachalam. V. (2018). Enhancing Interdisciplinary Research in Engineering Education. Fifth International Conference on Transformations on Engineering Education. Madurai: Theagarajar College of Engineering. India.

49. Anita. S. and Thanikachalam. V. (2010). Opportunities for Indian Engineering and Technical Institutes to offer Programs for Overseas Students and Establishing Overseas Institutes under Mode-2 and Mode-3 of GATS, Journal of Engineering and Technology Education, 4(2) 